ARTIKEL PENELITIAN

\title{
Hubungan gangguan pendengaran dengan penurunan fungsi kognitif pada usia lanjut
}

\author{
Ade Asyari ${ }^{1,3}$, Hendra Permana ${ }^{2,3}$, Al Hafiz ${ }^{1,3}$, Rossy Rosalinda ${ }^{1,3}$ \\ 1. Bagian IImu Kesehatan THT-KL, Fakultas Kedokteran, Universitas Andalas; 2. Bagian IImu Penyakit \\ Saraf, Fakultas Kedokteran, Universitas Andalas; 3. RSUP dr. M. Djamil, Padang
}

Korespondensi: Ade Asyari; email: adeasyari2@gmail.com

\begin{abstract}
Abstrak
Tujuan: Mengetahui hubungan antara gangguan pendengaran dengan penurunan fungsi kognitif pada usia lanjut. Metode: Menggunakan metode studi potong lintang pada kelompok usia lanjut yang menghuni panti sosial Tresna Werdha Kasih Sayang lbu di Batusangkar dari bulan Juli sampai September 2017. Terdapat 38 orang usia lanjut lebih dari 60 tahun yang masing-masingnya dilakukan pemeriksaan fungsi kognitif dengan Mini Mental State Examination (MMSE) dan pemeriksaan fungsi pendengaran dengan Oto Acoustic Emission (OAE). Data kemudian dianalisis dengan Fisher Exact Test dimana nilai $p<0,5$ dianggap bermakna. Hasil: Didapatkan median umur 71 tahun (60-86 tahun), jenis kelamin laki-laki sebanyak 76,3\%, fungsi kognitif terganggu sebanyak 68,4\% dan pendengaran terganggu sebanyak 68,4\%. Simpulan: Terdapat hubungan antara gangguan pendengaran dengan fungsi kognitif pada usia lanjut.
\end{abstract}

Kata kunci: gangguan pendengaran; usia lanjut; fungsi kognitif; mini mental state examination; oto accoustic emmision

\begin{abstract}
Objective: To examine the relationship between hearing impairment with decreasing of cognitive function in elderly. Method: Using cross sectional study design on elderly group of people who inhabitted social institution Tresna Werdha Kasing Sayang Ibu, Batusangkar since July until September 2017. There were 38 elderly people over 60 years old, each of them was performed a cognitive function examination using Mini Mental State Examination (MMSE) and hearing function examination using Oto Acoustic Emission (OAE). The data were analyzed using Fisher Exact Test where $p<0.5$ was considered significant. Results: We obtained median age was 71 years old (60-86 years old) with $76.3 \%$ occurred in man, impairment cognitive function and hearing impairment was $68.4 \%$. Conclusion: There was relation between hearing impairment with cognitive function in elderly.
\end{abstract}

Keywords: hearing impairment; elderly; cognitive function; mini mental state examination; oto acoustic emission 


\section{PENDAHULUAN}

Secara global prevalensi tuli sensorineural pada usia lanjut (presbikusis) bervariasi, diperkirakan terjadi pada $30-45 \%$ orang dengan usia di atas 65 tahun. Menurut WHO pada tahun 2005 akan terdapat 1,2 milyar orang akan berusia lebih dari 60 tahun, dari jumlah tersebut $60 \%$ diantaranya tinggal di negara berkembang. Menurut perkiraan WHO pada tahun 2020 populasi dunia berusia di atas 80 tahun juga akan meningkat sampai $200 \%$. Pada Survei Kesehatan Indera Penglihatan Pendengaran tahun 1994-1996 di 7 Provinsi (Sumatera Barat, Sumatera Selatan, Jawa Tengah, NTB, Sulawesi Selatan dan Sulawesi Utara) dengan 19,375 responden didapatkan prevalensi presbikusis sebesar 2,6\% atau sekitar $6,7 \%$ dari seluruh pasien THT yang didiagnosis dengan Presbikusis. Presbikusis dianggap sebagai salah satu penyebab terjadinya gangguan fungsi kognitif pada usia lanjut. ${ }^{1-}$ 4

\section{METODE}

Merupakan penelitian potong lintang (cross sectional study) di panti sosial Tresna Werdha Kasih Sayang Ibu Batusangkar dan Bagian Telinga Hidung Tenggorok Bedah Kepala Leher (THT-KL) serta Bagian IImu Penyakit Saraf RSUP dr. M. Djamil Padang dari bulan Juni sampai September 2017. Sebanyak 70 populasi penghuni panti sosial, 38 di antaranya yang memenuhi kriteria penerimaan sebagai sampel penelitian. Kriteria inklusi (penerimaan) pada penelitian ini adalah usia $>60$ tahun, dapat menjalani prosedur penelitian dan bersedia ikut dalam penelitian. Sedangkan kriteria eksklusi (penolakan) adalah jika sedang mengalami infeksi akut (demam $>38,5^{\circ} \mathrm{C}$ dan leukosit dalam batas normal $6.000-10.000 / \mathrm{mL}$ ) dan sedang penderita penyakit kronis lainnya yang memerlukan perawatan dan pengobatan khusus. dengan melakukan penelitian pada 38 usia lanjut yang memenuhi kriteria inklusi dan tidak termasuk pada kriteria eksklusi. Pengambilan sampel penelitian dimulai setelah mendapatkan persetujuan dari komite etik RSUP dr. M. Djamil Padang dan seluruh subjek penelitian telah diberikan informasi dan menandatangani surat persetujuan sebelum dilakukan pemeriksaan.

Proses penelitian dimulai dengan pengumpulan data dan alat-alat pemeriksaan. Sebelumnya para usia lanjut diberikan penyuluhan sederhana bagaimana menjaga dan memelihara kesehatan telinga dan pendengaran serta penyuluhan mengenai pentingnya menjaga fungsi kognitif otak pada usia lanjut. Lalu dilakukan pemeriksaan untuk mengetahui adanya gangguan pendengaran dan menilai fungsi kognitifnya. Data diperoleh dengan wawancara dengan sampel yang dicatat hasilnya oleh peneliti dalam status penelitian dengan pertanyaan yang sudah dibuat secara baku. Pemeriksaan fungsi kognitif dengan MMSE dilakukan oleh bagian Neurologi RSUP dr M Djamil Padang, dan fungsi pendengaran dilakukan 
oleh subbagian Neurotologi THT-KL RSUP dr M Djamil Padang.

\section{HASIL DAN PEMBAHASAN}

Telah dilakukan penelitian mengenai hubungan fungsi kognitif dengan gangguan pendengaran pada penghuni panti sosial Tresna Werdha Batusangkar, dimana didapatkan sebanyak 38 subyek yang mengikuti penelitian ini. Subyek dipilih sesuai dengan kriteria penerimaan dari 70 orang penghuni, dimana 32 orang lainnya tidak dimasukkan dalam penelitian. Sebanyak 5 orang menolak untuk melanjutkan penelitian, 3 orang tidak mengikuti penelitian karena sakit kronis, 24 orang tidak dimasukkan ke dalam penelitian karena data yang tidak lengkap saat penelitian dilaksanakan.

Tabel 1. Karakteristik Dasar Sampel

\begin{tabular}{lc}
\hline Karakteristik Dasar (N=38) & Frekuensi \\
\hline Jenis kelamin, laki-laki, $\mathrm{n}(\%)$ & $29(76,3)$ \\
Usia, median (min-maks) & $71(60-86)$ \\
Tingkat Pendidikan, $\mathrm{n}(\%)$ & \\
$\quad$ Tidak sekolah & $9(23,7)$ \\
SD & $14(36,8)$ \\
SMP & $8(21,1)$ \\
SMA & $7(18,4)$ \\
\hline
\end{tabular}

Sampel dengan jenis kelamin laki-laki merupakan kelompok yang terbanyak pada penelitian ini, yaitu 29 orang $(76,3 \%)$. Rerata usia sampel adalah 72 tahun, dan median umur adalah 71 tahun. Usia termuda yang mengikuti penelitian ini adalah 60 tahun, dan usia tertua adalah 86 tahun. Sebagian besar subyek memiliki tingkat pendidikan rendah, dan terbanyak tingkat pendidikannya tamat SD, yaitu 14 orang $(36,8 \%)$. Hanya 7 orang $(18,4 \%)$ yang memiliki tingkat pendidikan yang baik (tamat SMA). Karakteristik dasar dari sampel penelitian ditampilkan dalam Tabel 1.

Setelah dilakukan pemeriksaan fungsi kognitif dan pendengaran pada subyek, didapatkan $31 \%$ dengan fungsi kognitif normal (nilai skor MMSE >25). Rerata skor MMSE yang didapatkan dari penelitian ini adalah 21, skor paling rendah adalah 10 dan tertinggi adalah 29. Sedangkan skor MMSE 26 adalah hasil terbanyak yang ditemukan, yaitu pada 6 orang subyek $(15,8 \%)$.

Tabel 2. Gambaran fungsi kognitif dan pendengaran pada sampel

\begin{tabular}{lc}
\hline Variabel $(\mathrm{N}=38)$ & Frekuensi \\
\hline $\begin{array}{l}\text { Skor MMSE, median (min- } \\
\text { maks) }\end{array}$ & $22(10-29)$ \\
$\begin{array}{l}\text { Fungsi kognitif, terganggu n } \\
(\%)\end{array}$ & $26(68,4)$ \\
$\begin{array}{l}\text { Fungsi pendengaran, } \\
\text { terganggu, } \mathrm{n}(\%)\end{array}$ & $26(68,4)$ \\
\hline
\end{tabular}

Dari hasil pemeriksaan fungsi pendengaran, sebagian besar (68,4\%) subyek mengalami gangguan pendengaran. Gangguan fungsi pendengaran ini terutama pada kelompok usia di atas 70 tahun (data tidak ditampilkan). Tabel 2 menampilkan gambaran fungsi kognitif dan pendengaran pada subyek yang mengikuti penelitian.

Gangguan kognitif memiliki hubungan dengan penurunan fungsi pendengaran pada subyek penelitian. Hasil analisis dengan Fisher's Exact Test menunjukkan hubungan yang bermakna antara kedua variabel tersebut $(p=0,026)$. Sebagian besar subyek dengan pendengaran terganggu (21 orang, 55,3\%) mengalami gangguan 
kognitif, sedangkan pada kelompok dengan pendengaran normal didapatkan 5 orang $(13,2 \%)$ yang mengalami gangguan fungsi kognitif. Nilai Odd's ratio dari uji ini sebesar 5,88 yang menunjukkan bahwa mereka yang memiliki gangguan pendengaran akan berisiko 5 kali lipat mengalami gangguan kognitif dibandingkan dengan yang tidak terganggu pendengarannya. Tabel 3 menampilkan hubungan kedua variabel.

Tabel 3. Hubungan antara fungsi pendengaran dengan fungsi kognitif

\begin{tabular}{|c|c|c|c|c|c|}
\hline \multirow[t]{2}{*}{ Fungsi pendengaran } & \multicolumn{3}{|c|}{ Fungsi kognitif } & \multirow[t]{2}{*}{$\mathrm{p}$} & \multirow[t]{2}{*}{ OR } \\
\hline & Normal & Terganggu & Total & & \\
\hline Normal, n (\%) & $7(18,4)$ & $5(13,2)$ & $12(31,6)$ & \multirow{2}{*}{0,026} & \multirow{2}{*}{5,88} \\
\hline Terganggu, n (\%) & $5(13,2)$ & $21(55,3)$ & $26(68,4)$ & & \\
\hline
\end{tabular}

Uji variabel perancu juga dilakukan dalam penelitian ini. Salah satu variabel yang mempengaruhi adalah tingkat pendidikan.

Sebagian besar kelompok yang memiliki gangguan kognitif berada pada tingkat pendidikan rendah (57,9\%), meskipun demikian tidak terdapat hubungan antara kedua variabel secara statistik, dimana nilai p dari uji tersebut adalah 0,879 . Data tidak ditampilkan.

Dilakukan analisa dari hasil penelitian ini, didapatkan adanya hubungan yang bermakna antara fungsi pendengaran yang terganggu dengan penurunan fungsi kognitif. Sebagian besar subyek mengalami gangguan pendengaran dan juga memiliki fungsi kognitif terganggu. Gangguan fungsi kognitif ini terlihat jelas dari rerata skor MMSE 21, dimana hal ini menunjukkan adanya gangguan kognitif tingkat sedang. Hubungan ini tidak dipengaruhi oleh tingkat pendidikan sebagai salah satu faktor perancu yang berperan, dimana dalam hasil uji tidak terdapat hubungan yang bermakna. Lebih lanjut lagi, dari analisis didapatkan risiko gangguan fungsi kognitif pada subyek yang mengalami gangguan pendengaran sebesar 5,88 kali.
Besarnya risiko ini mirip dengan hasil penelitian Lin et $\mathrm{al}^{6}$ yang menyimpulkan bahwa penderita gangguan pendengaran derajat ringan, sedang, dan berat berisiko 2 hingga 5 kali lipat mengalami demensia.

Risiko gangguan pendengaran pada usia di atas 65 tahun bervariasi, namun diperkirakan sekitar $40-50 \%$ populasi usia tersebut mengalami gangguan pendengaran. Risiko tersebut meningkat jauh menjadi $83 \%$ saat mencapai usia 70 tahun. ${ }^{5}$ Risiko terjadinya demensia juga meningkat setiap 20 tahun di periode usia lanjut. ${ }^{6} \mathrm{Hal}$ ini membutuhkan perhatian, mengingat beberapa studi menunjukkan bahwa gangguan pendengaran merupakan faktor independen pencetus demensia dan gangguan fungsi kognitif. Bagaimanapun, masih banyak terdapat data yang bertolak belakang, sehingga belum bisa menghasilkan kesimpulan yang tajam. ${ }^{6}$

Hubungan antara fungsi pendengaran dan kognitif dapat diterangkan melalui beberapa mekanisme. Salah satu teori yang menjelaskan hubungan tersebut adalah berkurangnya sel rambut pada membran basilar kokhlea yang menyebabkan hilangnya kemampuan menangkap suara 
dengan frekuensi tinggi. Gangguan tersebut selanjutnya akan mempengaruhi persepsi dalam berbicara. Gangguan persepsi ini akan berakibat pada kesulitan dalam menyimpan memori yang bersifat auditorik, terganggunya pemahaman terhadap proses bicara kompleks. Upaya untuk meningkatkan kemampuan pendengaran sendiri menciptakan stres pada penderita, yang selanjutnya mungkin akan memperberat gangguan fungsi kognitifnya. ${ }^{5,7-10}$

Penelitian ini masih memiliki keterbatasan, sehingga belum bisa menghasilkan kesimpulan yang lengkap mengenai hubungan kedua variabel. Pertama, pemeriksaan pendengaran hanya dilakukan dalam satu waktu. Studi yang berskala besar oleh Lin et al $^{5}$ di Baltimore melakukan pemeriksaan fungsi pendengaran secara berkala, dari tahun 1990 sampai 1994. Perubahan fungsi pendengaran selanjutnya dianalisis apakah memang memiliki pengaruh terhadap fungsi kognitif. Tentunya tidak cukup hanya dilakukan satu pemeriksaan saja untuk mengambil kesimpulan. Kedua, pemeriksaan fungsi kognitif yang dilakukan kepada subyek (MMSE) hanya terbatas pada variabel kognitif standar, sehingga kurang mencerminkan domain kognitif mana yang lebih rentan terkena pada mereka yang mengalami gangguan pendengaran. Beberapa studi menggabungkan hasil pemeriksaan MMSE dengan model pemeriksaan yang spesifik pada domain verbal dan persepsi bicara, seperti Verbal Learning and Memory Test (VLMT), International Speech Test Signal (ISTS), Letter and Category Fluency, dan lain-lain. ${ }^{15}$ Untuk itu, diperlukan studi lanjutan untuk menilai apakah gangguan pendengaran lebih spesifik mempengaruhi domain persepsi bicara dan kemampuan verbal pada usia lanjut. ${ }^{5,7,11-16}$

\section{SIMPULAN}

Terdapat gangguan fungsi pendengaran dan fungsi kognitif pada sebagian besar subyek penelitian. Selanjutnya juga ditemukan hubungan yang bermakna antara gangguan pendengaran dengan penurunan fungsi kognitif, dimana subyek dengan gangguan pendengaran memiliki risiko mengalami gangguan kognitif sebesar 5,88 kali dibandingkan mereka yang tidak mengalami gangguan.

\section{UCAPAN TERIMA KASIH}

Terima kasih kepada seluruh penghuni panti sosial Tresna Werdha Kasih Sayang Ibu Batusangkar, pembimbing konsultan di bagian IImu THT-KL dan Neurologi RSUP dr. M. Djamil Padang, rekan-rekan residen dan seluruh tenaga medis di poliklinik THT-KL dan Neurologi RSUP dr. M. Djamil Padang. 


\section{DAFTAR PUSTAKA}

1. Djafar ZA, Helmi, Restuti RD. Kelainan Telinga Tengah. Dalam: Soepardi EA, Iskandar N, Bashiruddin J, Restuti RD, editor. Buku Ajar Ilmu Kesehatan Telinga Hidung Tenggorok Kepala dan Leher. Edisi ke-6. Jakarta: Balai Penerbit Fakultas Kedokteran Universitas Indonesia; 2007. p64-86.

2. World Health Organization. Chronic suppurative otitis media: burden of illness and management options. [internet]. Geneve: World Health Organization; 2004. [Link].

3. The Closing the Gap Clearinghouse. Ear disease in aboriginal and torres strait islander children. [internet]. Canberra: Australian Institute of Health and Welfare; 2014. [Link].

4. Menteri Kesehatan RI. Keputusan Menteri Kesehatan Republik Indonesia No.879/Menkes/SK/XI/2006 tentang Rencana Strategi Nasional Penanggulangan Gangguan Pendengaran dan Ketulian Untuk Mencapai Sound Hearing 2030. Jakarta: Departemen Kesehatan RI; 2006.

5. Wingfield A, Peelle JE. How does hearing loss affect the brain?. Aging Health. 2012; 8(2):107-9. doi: 10.2217/AHE.12.5. [PMC free article].

6. Lin FR, Yaffe K, Xia J, Xue QL, Harris TB, Purchhase-Helzner E, et al. Hearing Loss and Cognitive Decline Among Older Adults. JAMA Intern Med. 2013; 173(4). doi: 10.1001/iamainternmed.2013.1868. [PMC free article].

7. Meister H, Schreitmüller S, Grugel L, Beutner D, Walger M, Meister I. Examining speech preception in noise and cognitive functions in elderly. Am J Audiol. 2013; 22(2):310-2. doi: 10.1044/10590889(2012/12-0067). [PubMed].

8. Mehta R, Zhu R, Cheema. Is Noise Always Bad? Exploring the Effects of Ambient Noise on Creative Cognition. Journal of Consumer Research. 2012; 39(4):784-99. doi: 10.1086/665048. [Abstract/FREE full-text].

9. Mamonto ND, Porotu J, Waworuntu O. Pola Bakteri Aerob Pasien dengan Diagnosis Otitis Media Supuratif Akut di Poliklinik THT-KL RSUP Prof. DR. R.D. Kandaou Manado. e-Biomedik. 2015; 3(1):269-73. doi: 10.35790/ebm.3.1.2015.6844.

10. Helmi. Komplikasi otitis media supuratif kronis dan mastoiditis. Dalam: Soepardi EA, Iskandar N, Bashiruddin J, Restuti RD, editor. Buku Ajar Ilmu Kesehatan Telinga Hidung Tenggorok Kepala dan Leher. Edisi ke-6. Jakarta: Balai Penerbit Fakultas Kedokteran Universitas Indonesia; 2007.

11. Dugdale AE. Management of chronic suppurative otitis media. Med J Aust. 2004; 180(2):91-3. doi: 10.5694/j.1326-5377.2004.tb05809.x.

12. Paparella MM, Adams GL, Levine SC. Penyakit telinga tengah dan mastoid. Dalam: Wijaya C, penerjemah. Effendi H, Santoso K, editor. BOIES Buku Ajar Penyakit THT. Edisi 6. Jakarta: EGC; 1997.

13. Browning GG, Merchant SN, Kelly G, Swan IRC, Canter R, McKerrow WS. Chronic otitis media. In: Gleeson MJ, Clarke R, eds. Scott-Brown's Otorhinolaryngology: Head and Neck Surgery $7^{\text {th }}$ Ed, Vol 3. London: Hodder Arnold; 2008. p.3395-3445.

14. Couzos S, Lea T, Mueller R, Murray R, Culbong M. Effectiveness of ototopical antibiotics for chronic suppurative otitis media in Aboriginal children: a community-based, multicentre, double-blind randomised controlled trial. Med J Aust. 2003; 179(4):185-90. [PubMed]. 
15. Liu L, Shen Pei, He T, Chang Y, Shi L, Tao S, Li X, Xun Q, Guo X, Yu Z, Wang J. Noise induced hearing loss impairs spatial learning/memory and hippocampal neurogenesis in mice. Scientific Reports. 2016; 6:20374. doi: 10.1038/srep20374.

16. Peracino A, Pecorelli S. The Epidemiology of Cognitive Impairment in the Aging Population: Implications for Hearing Loss. Audiol Neurootol. 2016; 21(Suppl 1):3-9. doi: 10.1159/000448346. [PubMed]. 